\title{
Religiosity Moderation On The Effect Of Reward System And Motivation On Work Performance
}

\author{
${ }^{1}$ Hayat, ${ }^{2}$ Sumartono, ${ }^{3}$ Choirul Saleh, ${ }^{4}$ Ratih Nur Pratiwi \\ Faculty of Administrative Sciences Brawijaya University, Malang, East Java, Indonesia \\ ${ }^{1}$ hayat@unisma.ac.id
}

\begin{abstract}
Purpose: This paper aims to Religiosity Moderation On The Effect Of Reward System And Motivation On Work Performance.

Design/methodology/approach: The method used is statistic-descriptive and the design used is cross sectional.

Findings: 4 hypotheses are while the other is accepted.

Research limitations/implications: The population size in 3 (three) OPDs selected as research locations, based on data from the Central Statistics Agency (BPS) in 2017, amounted to 207 people with details: Dispendukcapil(Department of Population and Civil Registration)as many as 73 people, DPMPTSP as many as 43 people and RSUD as many as 93 people.
\end{abstract}

Practical implications: Results show that from the 4 hypotheses proposed.

Originality/value: This paper is original.

Paper type: This paper can be categorized as a case study.

Keyword: Reward System, Motivation, Work Performance, Religiosity

\begin{tabular}{lll}
\hline Received & $:$ December $12^{\text {th }} 2019$ \\
Revised & $:$ February $17^{\text {th }} 2020$ \\
Published & $:$ March $30^{\text {th }} 2020$ \\
\hline
\end{tabular}

\section{INTRODUCTION}

The improvement in ASN's performance and performance is based on a better assessment process. Using assessment instruments independently is expected to improve ASN performance. A reward and punishment system also applies, so that it can improve work quality, capacity, capability and integrity. The granting of such benefits is also carried out by the government with the level of performance for ASN which is expected to be increased and maximized. However, the policy of providing employee performance benefits that can increase the amount of their income from the previous one has not been able to reduce the level of corruption expected (Setiawan, 2018).

Work performance can be done based on the results of performance measurements. Performance measurement is based on the performance of the state civil servants in accordance with their duties and principles. Performance appraisal is an inseparable part of providing quality services. Performance assessment is an evaluation of the performance of the state civil apparatus in carrying out its duties 
and functions. Is it in accordance with the provisions and regulations in force or not. Is it running well or not. Performance appraisal is the basis of improvements to public services.

Azizy (2007) also revealed that control and supervision can be carried out effectively and efficiently if there are standards, indicators or factors that can be measured easily and clearly. Not only qualitative or based on estimates or feelings. When there is no standardization, judgment will most likely be dominated by subjective feelings. Organizations should have 4 important things related to organizational performance to achieve goals, namely performance standards, performance measurement, performance evaluation, and correlation and performance improvement.

As regulated in Government Regulation Number 46 of 2011 Concerning Assessment of Work Performance of Civil Servants article 5 as follows: (1) every civil servant is required to prepare SKP as referred to in Article 4 letter a based on the annual work plan of the institution; (2) SKP as referred to in paragraph (1) shall contain the activities of the official duties and targets that must be achieved within a period of real and measurable assessments; (3) SKP that has been prepared as referred to in section (1) must be approved and determined by the appraisal official; (4) If the SKP compiled by the civil servant is not approved by the appraisal official, the decision shall be submitted to the appraisal superior; (5) SKP as referred to in paragraph (1) is stipulated annually in January; (6) if there isa transfer of employees after January, the person concerned will still draw up the SKP at the beginning of the month in accordance with the order to carry out the duties or the order to occupy the position.

On the other hand, assessment-using SKP also has an weaknesses. Some preliminary findings in the field, that filling out the performance appraisal using SKP was also filled in by the administration section which was then submitted to his supervisor to be verified.

The work performance of the apparatus is an indicator of good service quality as part of the process of achieving the objectives of the governmental organization. The state civil apparatus demanded to continue to increase and strengthen the capacity continuously in the administration of public services.

However, to get good work performance, it is necessary to have a strong involvement of the apparatus in carrying out their duties and functions. The organization is a system that is built based on the rules and regulations that apply in it. Therefore, all stakeholders in the organization must submit to and obey the rules of the organization. Work engagement is the involvement of employees in their organizations. Through good involvement,we have an impact on the performance of the apparatus by utilizing its potential. Finally, it will have a good impact on the organization.

Schaufeli (2004) revealed that work engagement is a statement of positive thoughts and fulfillment related to work and pleasant experiences for employees, namely through vigor, dedication, and absorption. More detailed,it explained that in accordance with the results of his research showed that positive attitudes towards 
work such as job satisfaction, work involvement, organizational commitment and low intention to leave associated with work engagement. Every employee is not only interested in the aspect of work that gives meaning, but they actively look for it in their work as a means to be committed to the organization

According to Putriani's opinion (Putriani \& Shofawati, 2015) that religiosity as a variety of religious aspects, it include kind of dimension, not only occur when someone do ritual behavior, but also when carrying out other activities that are driven by supernatural powers. It means the religiosity is how capable individuals carry out aspects of religious beliefs in religious life and other social lives. Therefore, religiosity can moderate apparatus motivation on work performance, on work performance and engagement, in order to build spiritual power by carrying out religious values, called hablumminallah wa hablunminannas.

Therefore, work performance achieved through strengthening the religious values. Indaily life it alsosupport in forming the character of the apparatus. Good and competence apparatus can do their duties and function to give quality and excellent service to community

Similarly, (Fowler, 1995) revealed, the religiosity function is encouraging, supporting, channeling, and being a reference for all our feelings and relationships with transcendence, it can direct our desires and hopes. Therefore, the fulfillment of the work is not merely to fulfill the needs, but also makes it an obligation that can be accounted to God Almighty. to get His pleasure. Work is part of worship, so do it according to your obligations by expecting God to give the best in our life.

Reward system must build as an effort to stimulate the state civil apparatus in working and improve their quality of self to be more in accordance with their competencies. In addition, the reward system is a support for the state civil apparatus to build quality culture and character of the apparatus. We hope through the reward system, the state civil apparatus will be more enthusiastic and active in their work, because each spirit is valued and rewarded.

Reward system is a reward given to motivate employees to produce high productivity. Various kinds of rewards given to employees based on work performance, including salaries, bonuses, incentives and promotions (Tohardi, 2002).

\section{A. Previous Study}

These conditions supported by the existence of a reward system (awarding) for state civil servants who get achievements as a form of prizes in order to become better and become a motivation for civil servants of other countries. Reward system is given on the basis of rewards for the performance that has been done with a positive impact on the institution. The reward system is expected to have the value of enthusiasm to maximize every potential of the state civil apparatus in order to compete in achieving work performance.

Based on research gaps and research limitations, the formulation of the problem is whether the reward system has a positive and significant effect on the motivation of the state civil apparatus; does the reward system have a positive and significant effect on the work performance of the civil service; does religiosity

Religiosity Moderation On The Effect Of Reward System And Motivation On Work Performance Hayat, Sumartono,Choirul Saleh,Ratih Nur Pratiwi

Page | 154 
moderate the effect of motivation on the work performance of the civil service; does religiosity moderate the effect of the reward system on the work performance of the civil service. The aim is to determine the effect of the reward system on the work motivation of the state civil apparatus; the effect of the reward system on the work performance of the civil service; the impact of religiosity on the influence of motivation on work performance of the state civil apparatus; and the impact of religiosity on the effect of the reward system on the work performance of the state civil service.

\section{B. Hypothesis}

H1: The effect of the reward system on motivation

$\mathrm{H} 2$ : The effect of the reward system on work performance

H3: The Role of Religiosity as Moderation in the Effect of Motivation on Work Performance

H4: The Role of Religiosity as Moderation in the Effect of Reward Systems on work Performance

\section{METHOD}

This study used quantitative approach. The data analysis was performed using structural equation modeling (SEM) with used the WarpPLS approach. The calculation process is carried out with the help of a statistical computer program, WarpPLS 6.0. SEM is a statistical tool used to solve multilevel models simultaneously which cannot be solved by linear regression equations.

Referring to the characteristics of the research subjects needed for the purposes of data analysis, the sample unit in this study is the individual civil service. While the Regional Government Organization (OPD) / Regional Government Work Unit (SKPD) intended in this study is based on diverse aspects of religious adherents, has a vision and mission to strengthen religiosity in organizational development and has achievements and awards in the quality of public services.

The population of this study is all state civil servants in 3 (three) DPOs selected as research locations. The population size in 3 (three) OPDs selected as research locations, based on data from the Central Statistics Agency (BPS) in 2017, amounted to 207 people with details: Dispendukcapil(Department of Population and Civil Registration)as many as 73 people, DPMPTSP as many as 43 people and RSUD as many as 93 people.

Primary data used in this study are perception data or respondents' assessment of the studied variables. Respondents in this study are state civil servants in 3 (three) OPDs who are asked to provide perceptions or assessments of research variables. This is because the variables studied are an attitude and / or behavior, in the form of a variable reward system, motivation, work performance and religiosity.

Primary data was collected through questionnaires. To get the data needed to support this research, data collection techniques used were by distributing questionnaires. 


\section{Reward System}

\section{RESULT AND DISCUSSION}

Reward System variable consists of four indicators, namely Incentives (X11), Salary (X12), Remuneration (X13), and Promotion (X14). Itsconsist of three items, while the Promotion indicator (X14) consists of four items. The following Table 6.6 presents the frequency, percentage, and average score for each item and indicator.

Table 1 Variable Description of Reward System

\begin{tabular}{|c|c|c|c|c|c|c|c|c|c|c|c|c|c|}
\hline \multirow{3}{*}{ Indicator } & \multirow{3}{*}{ Item } & \multicolumn{10}{|c|}{ Frequency and Percentage of Answers } & \multicolumn{2}{|c|}{ Score average } \\
\hline & & \multicolumn{2}{|c|}{ STS } & \multicolumn{2}{|c|}{ TS } & \multicolumn{2}{|c|}{$\mathrm{N}$} & \multicolumn{2}{|c|}{$\mathrm{S}$} & \multicolumn{2}{|c|}{ SS } & \multirow{2}{*}{ Item } & \multirow{2}{*}{ Indicator } \\
\hline & & $\mathrm{F}$ & $\%$ & $\mathrm{f}$ & $\%$ & $\mathrm{f}$ & $\%$ & $\mathrm{f}$ & $\%$ & $\mathrm{f}$ & $\%$ & & \\
\hline \multirow{3}{*}{$\mathrm{X} 11$} & $\mathrm{X} 111$ & 7 & 6 & 26 & 21 & 33 & 27 & 49 & 40 & 8 & 7 & 3,20 & \multirow{3}{*}{3,40} \\
\hline & $\mathrm{X} 112$ & 1 & 1 & 14 & 11 & 30 & 24 & 65 & 53 & 13 & 11 & 3,61 & \\
\hline & X113 & 9 & 7 & 16 & 13 & 32 & 26 & 52 & 42 & 14 & 11 & 3,37 & \\
\hline \multirow{3}{*}{ X12 } & X121 & 0 & 0 & 4 & 3 & 8 & 7 & 73 & 59 & 38 & 31 & 4,18 & \multirow{3}{*}{4,28} \\
\hline & X122 & 0 & 0 & 1 & 1 & 3 & 2 & 68 & 55 & 51 & 41 & 4,37 & \\
\hline & X123 & 0 & 0 & 0 & 0 & 7 & 6 & 75 & 61 & 41 & 33 & 4,28 & \\
\hline \multirow{3}{*}{ X13 } & X131 & 0 & 0 & 1 & 1 & 14 & 11 & 77 & 63 & 31 & 25 & 4,12 & \multirow{3}{*}{4,22} \\
\hline & X132 & 0 & 0 & 0 & 0 & 13 & 11 & 73 & 59 & 37 & 30 & 4,20 & \\
\hline & X133 & 0 & 0 & 0 & 0 & 21 & 17 & 79 & 64 & 22 & 18 & 4,34 & \\
\hline \multirow{4}{*}{ X14 } & X141 & 1 & 1 & 14 & 11 & 34 & 28 & 57 & 46 & 17 & 14 & 3,61 & \multirow{4}{*}{3,89} \\
\hline & X142 & 0 & 0 & 1 & 1 & 25 & 20 & 74 & 60 & 23 & 19 & 3,97 & \\
\hline & X143 & 0 & 0 & 0 & 0 & 34 & 28 & 68 & 55 & 21 & 17 & 3,89 & \\
\hline & X144 & 0 & 0 & 0 & 0 & 19 & 15 & 74 & 60 & 30 & 24 & 4,09 & \\
\hline \multicolumn{13}{|c|}{ Average Variable Score } & 3,95 \\
\hline
\end{tabular}

Source: Processed research data (2019)

Based on Table 1, the average score for the overall Reward System variable is 3.95 or included in the Height category. Incentive Indicator (X11) has an average score of 3.40 or included in the Medium category. Meanwhile, the Salary indicator (X12) has an average score of 4.28 or included in the High category. Furthermore Remunerization indicator (X13) has an average score of 4.22 or included in the High category. Promotion Indicator (X14) has an average score of 3.89 or included in the High category. The indicator that has the highest average score is Salary (X12). It means that the State Civil Apparatus in the Government of Malang City considers high Salary (X12), It is high as a form of Reward System.

Figure .1. the average score for each item is presented for the indicator indicators of the Reward System variable. 


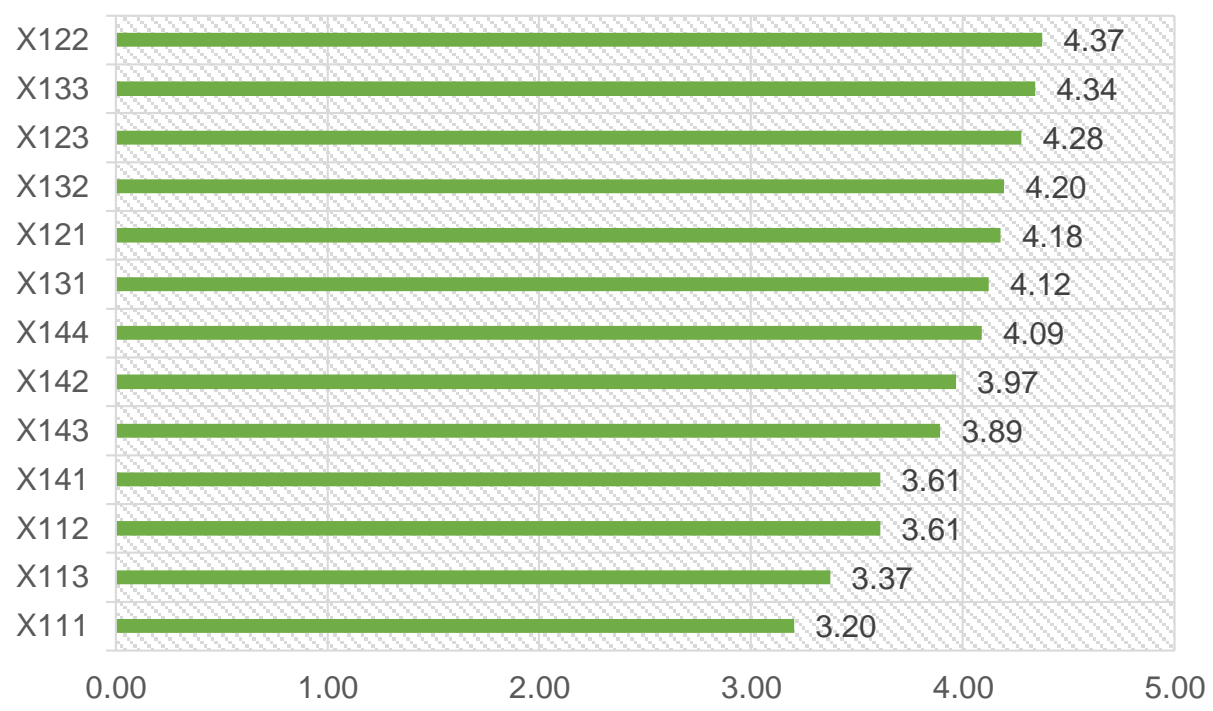

Figure 1 score average item on the Reward System variable

Figure 1 shows the highest average score items that have high enthusiasm at work (X122), which is 4.37. These items are included in the Height category. Meanwhile, the item with the lowest average score is the reward item in accordance with the achievements (X111), which is 3.20. These items are included in the Medium category.

From the picture above shows the State Civil Apparatus has a high enthusiasm at work, so that it is used as a form of high morale as a reward. To maintain the quality of performance and public service, high enthusiasm in working always needed

\section{Motivation}

Motivation variable consists of three indicators, they are Achievement (Y11), Affiliation (Y12), and Power (Y13). The Performance (Y11) and Affiliation indicator(Y12) consists of three items, while the Power Indicator (X23) consists of four items. In the following Table 6.7 the frequencies, percentages, and average scores for each item and indicator are presented.

Tabel 2 motivation variable description

\begin{tabular}{|c|c|c|c|c|c|c|c|c|c|c|c|c|c|}
\hline \multirow{3}{*}{ Indicator } & \multirow{3}{*}{ Item } & \multicolumn{10}{|c|}{ Frequency and Percentage of Answers } & \multicolumn{2}{|c|}{ Average score } \\
\hline & & \multicolumn{2}{|c|}{ STS } & \multicolumn{2}{|c|}{ TS } & \multicolumn{2}{|c|}{$\mathrm{N}$} & \multicolumn{2}{|c|}{$\mathrm{S}$} & \multicolumn{2}{|c|}{ SS } & \multirow{2}{*}{ Item } & \multirow{2}{*}{ Indicator } \\
\hline & & f & $\%$ & $f$ & $\%$ & $\mathrm{f}$ & $\%$ & $f$ & $\%$ & $f$ & $\%$ & & \\
\hline \multirow{3}{*}{ Y11 } & Y111 & 2 & 2 & 0 & 0 & 20 & 16 & 79 & 64 & 22 & 18 & 3,97 & \multirow{3}{*}{3,98} \\
\hline & Y112 & 0 & 0 & 2 & 2 & 32 & 26 & 76 & 62 & 13 & 11 & 3,81 & \\
\hline & Y113 & 1 & 1 & 3 & 2 & 28 & 23 & 76 & 62 & 14 & 11 & 4,15 & \\
\hline \multirow{3}{*}{ Y12 } & Y121 & 0 & 0 & 0 & 0 & 12 & 10 & 73 & 59 & 38 & 31 & 4,21 & \multirow{3}{*}{4,23} \\
\hline & Y122 & 0 & 0 & 0 & 0 & 10 & 8 & 76 & 62 & 37 & 30 & 4,22 & \\
\hline & Y123 & 0 & 0 & 0 & 0 & 15 & 12 & 61 & 50 & 47 & 38 & 4,26 & \\
\hline \multirow{2}{*}{ Y13 } & Y131 & 0 & 0 & 0 & 0 & 10 & 8 & 78 & 63 & 35 & 28 & 4,20 & \multirow{2}{*}{4,23} \\
\hline & Y132 & 0 & 0 & 1 & 1 & 7 & 6 & 77 & 63 & 38 & 31 & 4,24 & \\
\hline
\end{tabular}




\begin{tabular}{|c|c|c|c|c|c|c|c|c|c|c|c|c|c|}
\hline \multirow{3}{*}{ Indicator } & \multirow{3}{*}{ Item } & \multicolumn{10}{|c|}{ Frequency and Percentage of Answers } & \multicolumn{2}{|c|}{ Average score } \\
\hline & & \multicolumn{2}{|c|}{ STS } & \multicolumn{2}{|c|}{$\mathrm{TS}$} & \multicolumn{2}{|c|}{$\mathrm{N}$} & \multicolumn{2}{|c|}{$S$} & \multicolumn{2}{|c|}{ SS } & \multirow{2}{*}{ Item } & \multirow{2}{*}{ Indicator } \\
\hline & & $\mathrm{f}$ & $\%$ & $\mathrm{f}$ & $\%$ & $\mathrm{f}$ & $\%$ & $\mathrm{f}$ & $\%$ & $\mathrm{f}$ & $\%$ & & \\
\hline & Y133 & 0 & 0 & 1 & 1 & 7 & 6 & 86 & 70 & 29 & 24 & 4,16 & \\
\hline & Y134 & 0 & 0 & 0 & 0 & 9 & 7 & 68 & 55 & 46 & 37 & 4,30 & \\
\hline \multicolumn{4}{|c|}{ Average Variable Score } & & & & & & & & & & 4,14 \\
\hline
\end{tabular}

Source: Processed research data (2019)

Based on Table 1, the average score for the overall Motivation variable is 4.14 or included in the Height category. Performance Indicator (Y11) has an average score of 3.98 or included in the High category. Meanwhile, the Affiliate indicator (Y12) has an average score of 4.23 or included in the High category. Furthermore, the Power indicator (Y13) has an average score of 4.23 or included in the High category. The highest indicators of average score are Affiliation (Y12) and Power (Y13). It means that the State Civil Apparatus in the City Government of Malang considers the highest Affiliation (Y12) and Power (Y13) are as a form of motivation.

In Figure 2 below, the average scores for each item are presented for the indicators of the Motivation variable.

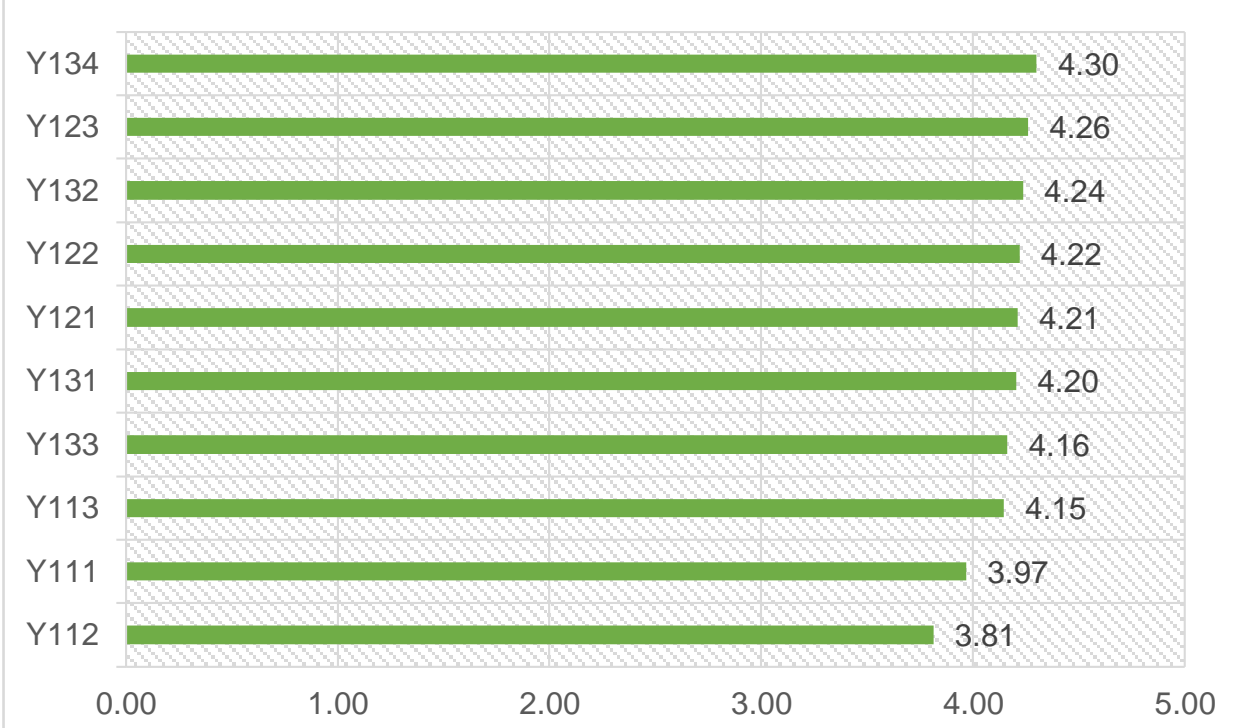

Figure 2 Average item scores on the Motivation variable

Figure 2 shows that the item with the highest average score is (Y134), which is 4.30. These items are included in the Height category. Meanwhile, the highest average score item was (Y112), which was 3.81. These items are included in the Medium category.

\section{Work Performance}

Work Performance Variable consists of six indicators, they are Quantity (Y31), Quality (Y32), Accuracy (Y33), Effectiveness (Y34), Attitude (Y35), and Independence (Y36). Indicators of Quantity (Y31), Quality (Y32), Accuracy (Y33), 
Effectiveness (Y34), Attitude (Y35), and Independence (Y36) consists of three items. The following Table 6.9 presents the frequency, percentage, and average score for each item and indicator.

Tabel 3 Description of work performance variables

\begin{tabular}{|c|c|c|c|c|c|c|c|c|c|c|c|c|c|}
\hline \multirow{3}{*}{ Indicator } & \multirow{3}{*}{ Item } & \multicolumn{10}{|c|}{ Frequency and Percentage of Answers } & \multicolumn{2}{|c|}{ Average score } \\
\hline & & \multicolumn{2}{|c|}{ STS } & \multicolumn{2}{|c|}{$\mathrm{TS}$} & \multicolumn{2}{|c|}{$\mathrm{N}$} & \multicolumn{2}{|c|}{$\mathrm{S}$} & \multicolumn{2}{|c|}{ SS } & \multirow{2}{*}{ Item } & \multirow{2}{*}{ Indicator } \\
\hline & & $\mathrm{f}$ & $\%$ & $\mathrm{f}$ & $\%$ & $f$ & $\%$ & $f$ & $\%$ & $f$ & $\%$ & & \\
\hline & Y311 & 0 & 0 & 2 & 2 & 11 & 9 & 74 & 60 & 36 & 29 & 4,17 & \\
\hline \multirow[t]{3}{*}{ Y31 } & Y312 & 0 & 0 & 0 & 0 & 8 & 7 & 78 & 63 & 37 & 30 & 4,24 & 4,19 \\
\hline & Y313 & 0 & 0 & 0 & 0 & 11 & 9 & 81 & 66 & 31 & 25 & 4,16 & \\
\hline & Y321 & 0 & 0 & 2 & 2 & 16 & 13 & 76 & 62 & 29 & 24 & 4,07 & \\
\hline \multirow[t]{3}{*}{ Y32 } & Y322 & 0 & 0 & 0 & 0 & 18 & 15 & 77 & 63 & 28 & 23 & 4,08 & 4,22 \\
\hline & Y323 & 0 & 0 & 0 & 0 & 10 & 8 & 77 & 63 & 35 & 28 & 4,52 & \\
\hline & Y331 & 0 & 0 & 1 & 1 & 24 & 20 & 70 & 57 & 28 & 23 & 4,02 & \\
\hline \multirow[t]{3}{*}{ Y33 } & Y332 & 0 & 0 & 1 & 1 & 13 & 11 & 76 & 62 & 33 & 27 & 4,15 & 4,04 \\
\hline & Y333 & 0 & 0 & 0 & 0 & 25 & 20 & 80 & 65 & 18 & 15 & 3,94 & \\
\hline & Y341 & 0 & 0 & 3 & 2 & 23 & 19 & 77 & 63 & 20 & 16 & 3,93 & \\
\hline \multirow[t]{3}{*}{ Y34 } & Y342 & 0 & 0 & 2 & 2 & 22 & 18 & 76 & 62 & 23 & 19 & 3,98 & 3,93 \\
\hline & Y343 & 1 & 1 & 1 & 1 & 24 & 20 & 83 & 67 & 14 & 11 & 3,88 & \\
\hline & Y351 & 0 & 0 & 1 & 1 & 26 & 21 & 79 & 64 & 17 & 14 & 3,91 & \\
\hline \multirow[t]{3}{*}{ Y35 } & Y352 & 0 & 0 & 1 & 1 & 12 & 10 & 86 & 70 & 24 & 20 & 4,08 & 4,04 \\
\hline & Y353 & 0 & 0 & 2 & 2 & 8 & 7 & 86 & 70 & 27 & 22 & 4,12 & \\
\hline & Y361 & 0 & 0 & 7 & 6 & 16 & 13 & 77 & 63 & 22 & 18 & 3,93 & \\
\hline \multirow[t]{2}{*}{ Y36 } & Y362 & 0 & 0 & 1 & 1 & 29 & 24 & 72 & 59 & 21 & 17 & 3,92 & 3,96 \\
\hline & Y363 & 0 & 0 & 0 & 0 & 19 & 15 & 82 & 67 & 22 & 18 & 4,02 & \\
\hline \multicolumn{4}{|c|}{ Average variable score } & & & & & & & & & & 4,06 \\
\hline
\end{tabular}

Source: Processed research data (2019)

Based on Table 3, the average score for the variable work Performance as a whole is 4.06 or included in the Height category. Quantity Indicator (Y31) has an average score of 4.19 or included in the High category. Meanwhile, the Quality indicator (Y32) has an average score of 4.22 or included in the High category. Furthermore, the Accuracy indicator (Y33) has an average score of 4.04 or included in the High category. Effectiveness Indicator (Y34) has an average score of 3.93 or included in the High category. Attitude Indicator (Y35) has an average score of 4.04 or included in the High category. The highest indicator of average score is Quality (Y32). It means that the State Civil Apparatus in Malang City Government considers that Quality (Y32) is already high as one form of Work Achievement.

In Figure 3, the following average scores for each item are presented for the indicators of the Work Performance variable. 


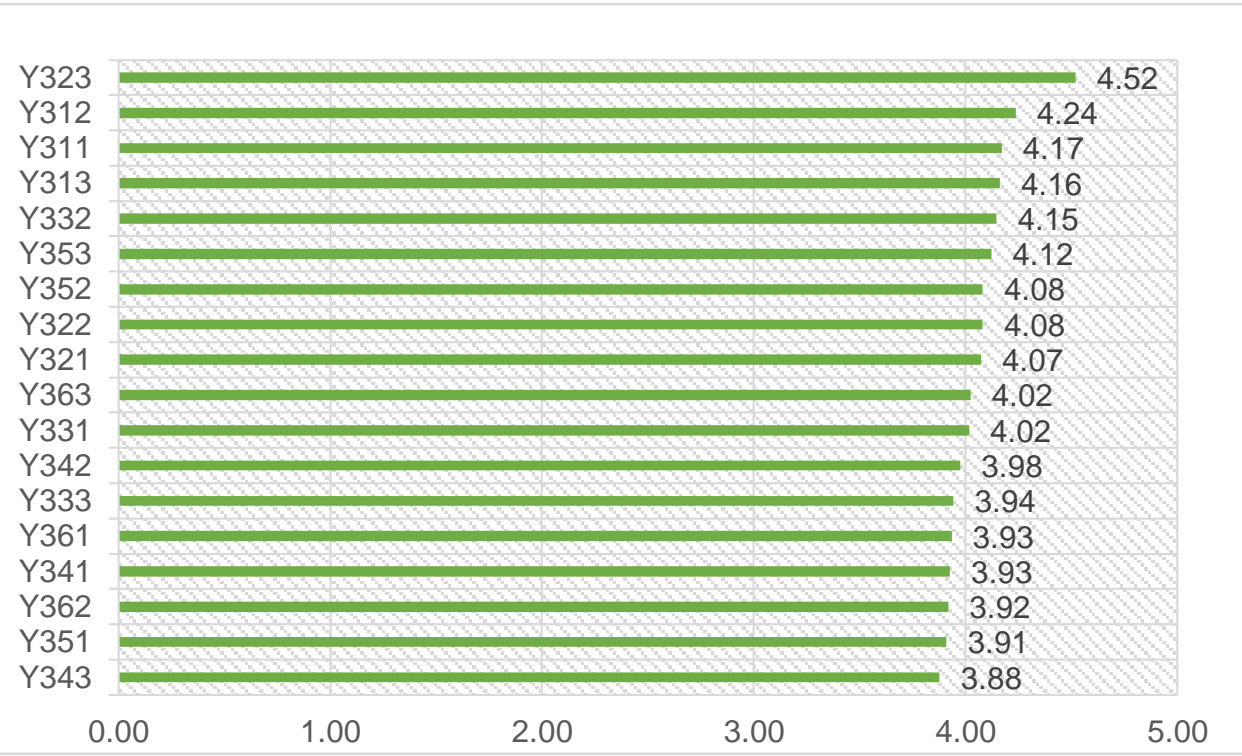

Figure 3 Average item scores on the Work Performance variable

Figure 3 shows the highest average score is (Y323), which is 4.52. These items are included in the Very High category. Meanwhile, the lowest item of average score is (Y343), which is 3.88. These items are included in the Medium category.

\section{Religiosity}

Religiosity Variable consists of five indicators, they are Ideological (M11), Intellectual (M12), Rituality (M13), Experience (M14), and Consequences (M15). Intellectual (M12), Rituality (M13), Experience (M14), and Consequences indicator (M15) consists of three items while Ideological (M11) consist of 4 items. In the following Table 4 the frequency, percentage, and average score for each item and indicator is presented.

Tabel 4 Religiosity Variable Desripsition

\begin{tabular}{|c|c|c|c|c|c|c|c|c|c|c|c|c|c|}
\hline \multirow{3}{*}{ Indicator } & \multirow{3}{*}{ Item } & \multicolumn{10}{|c|}{ Frequency and Percentage of Answers } & \multicolumn{2}{|c|}{ Average Score } \\
\hline & & \multicolumn{2}{|c|}{ STS } & \multicolumn{2}{|c|}{ TS } & \multicolumn{2}{|c|}{$\mathrm{N}$} & \multicolumn{2}{|c|}{$S$} & \multicolumn{2}{|c|}{ SS } & \multirow{2}{*}{ Item } & \multirow{2}{*}{ Indicator } \\
\hline & & $\mathrm{f}$ & $\%$ & $\mathrm{f}$ & $\%$ & $\mathrm{f}$ & $\%$ & $\mathrm{f}$ & $\%$ & $\mathrm{f}$ & $\%$ & & \\
\hline \multirow{4}{*}{ M11 } & M11 & 0 & 0 & 1 & 1 & 14 & 11 & 53 & 43 & 55 & 45 & 4,32 & \multirow{4}{*}{4,51} \\
\hline & M12 & 0 & 0 & 0 & 0 & 6 & 5 & 44 & 36 & 73 & 59 & 4,54 & \\
\hline & M13 & 0 & 0 & 0 & 0 & 5 & 4 & 51 & 41 & 66 & 54 & 4,82 & \\
\hline & M14 & 0 & 0 & 1 & 1 & 6 & 5 & 64 & 52 & 52 & 42 & 4,36 & \\
\hline \multirow{3}{*}{ M12 } & M21 & 0 & 0 & 2 & 2 & 12 & 10 & 72 & 59 & 37 & 30 & 4,17 & \multirow{3}{*}{4,24} \\
\hline & M22 & 0 & 0 & 0 & 0 & 13 & 11 & 68 & 55 & 42 & 34 & 4,24 & \\
\hline & M23 & 0 & 0 & 1 & 1 & 7 & 6 & 66 & 54 & 49 & 40 & 4,33 & \\
\hline \multirow{3}{*}{ M13 } & M31 & 0 & 0 & 0 & 0 & 12 & 10 & 68 & 55 & 43 & 35 & 4,25 & \multirow{3}{*}{4,14} \\
\hline & M32 & 0 & 0 & 1 & 1 & 23 & 19 & 59 & 48 & 40 & 33 & 4,12 & \\
\hline & M33 & 0 & 0 & 1 & 1 & 29 & 24 & 56 & 46 & 37 & 30 & 4,05 & \\
\hline
\end{tabular}




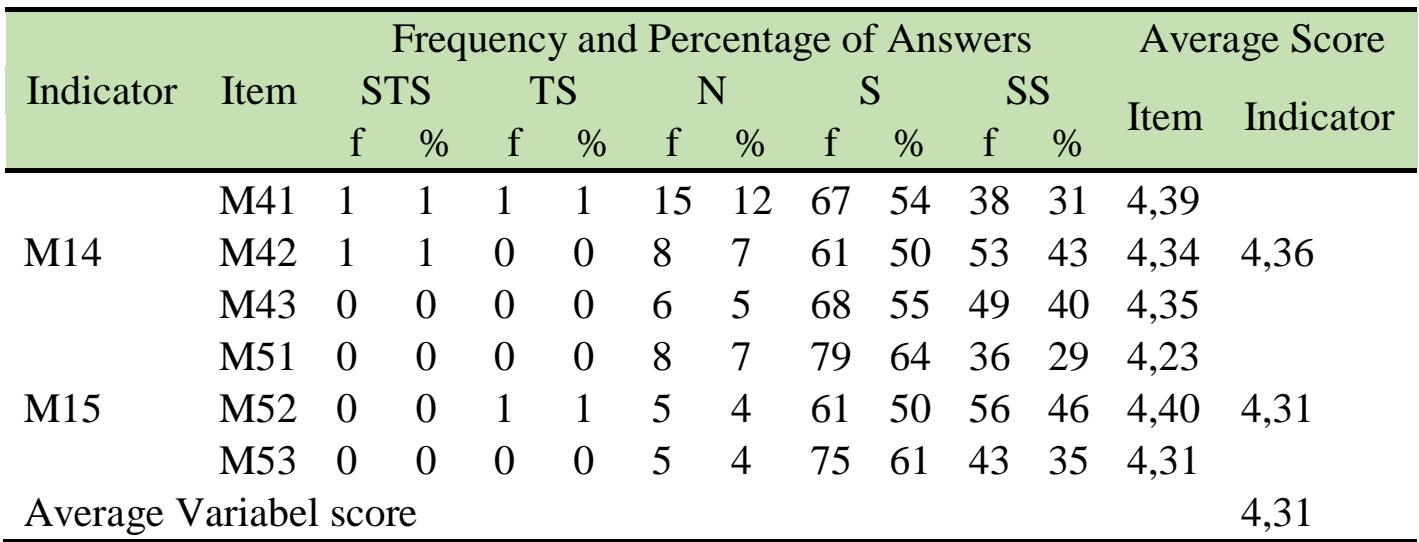

Source: Processed research data (2019)

Based on Table 4, the average score for the overall Religiosity variable is 4.31 or included in the Height category. Ideological Indicator (M11) has an average score of 4.51 or included in the category of Very High. Meanwhile, the Intellectual Indicator (M12) has an average score of 4.24 or included in the High category. Furthermore, the Rituality indicator (M13) has an average score of 4.14 or included in the High category. Experience Indicator (M14) has an average score of 4.36 or included in the High category. Attitude Indicator (M15) has an average score of 3.41 or included in the High category. The indicator that has the highest average score is Ideological (M11). This can be interpreted that the State Civil Apparatus in the City Government of Malang considers the highest ideological (M11) as a form of Work Achievement.

In Figure 4, the following average scores for each item are presented for the indicators making up the variable religiosity.

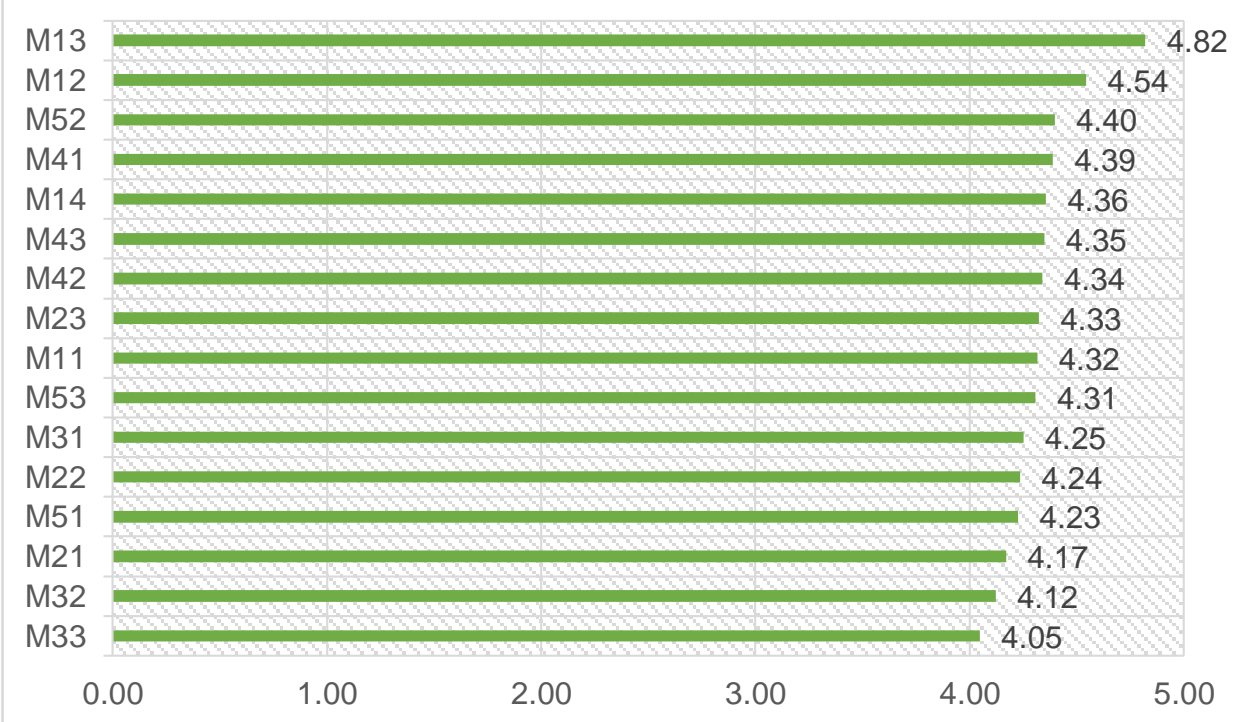

Figure 4 Average item scores on the Religiosity variable

Figure 4 shows that the item with the highest average score is (M13), which is 4.82. These items are included in the Very High category. Meanwhile, the item 
with the lowest average score is (M33), which is 4.05 . These items are included in the Height category.

\section{Reward System on Motivation Effect}

Reward system as an effort to improve the welfare and independence of the state civil servants built based on law and comprehensive provisions. The purpose of the reward is to encourage the state civil apparatus to be more creative, innovative, applicable and participatory in order to create better achievements and quality. The reward system for Existence can also improve social and economic well-being for the country, thereby ensuring family life and being able to focus more on hard working. Reward can also stimulate employees to improve performance discipline and it can increase hard work, smart work and fast work for employees and encourage quality service.

Hypothesis from data analysis shows that the reward system has a significant influence on achievement motivation. The average score of the reward system variable from the results of data analysis is high. It means, assessing that the reward system has an important role in influencing motivation. The higher rewards can be stimulatedemployees' motivation to work better. Thelower reward has an impact on the low work motivation of employees.

This study provides information that the reward system characterized by incentives, salaries, remuneration, and promotions has a positive and significant influence on motivation. Overall based on the factor loading measurement of each indicator shows the indicators determine the level of reward system. From the highest to the lowest indicator are indicators promotion, salary, remuneration and incentives. Therefore, it is important for heads of agencies to maintain promotional arrangements and payroll systems for employees so that it may continue to be a motivation at work. On the contrary, the remuneration and incentive indicators need to be improved. The higher the remuneration and incentives provided can strengthen employee motivation towards performance.

The results of this study reinforce the previous study submitted by (Pratheepkanth, 2011) which says that the reward system or expected benefits of employees can affect motivation at work. In order to employees always have high motivation to work as well as possible, therefore giving a reward is one of the most important things.

Armstrong (2010) his opinion was also clarified by the results of this study by saying that the importance of reward as a guarantee of motivation for employees for their work. Reward becomes very important for employees to build better performance. As stated by Armstrong and Taylor (Armstrong \& Taylor, 2014) that reward is a concrete picture aimed at employees as an appreciation for employee performance, thus providing a strong impetus to achieve better results on their work.

The reality shows the employees who are highly motivated are employees who are given a good incentive when giving achievements, salary that is periodically and disciplined, remuneration accordingly given according to the 
workload and promotions given to employees who have high achievements, increase productivity and his competence. So it is important for each department to pay attention to aspects of the reward system as part of the influence that can motivate employees to work better, perform higher, and can improve quality of service excellence.

\section{Effect of Reward System on Work Performance}

The results showed the reward system given to employees did not have a positive and significant effect on work performance. This is because the pathway coefficient obtained and the P-Value in table 6 is greater than 0.05 , the effect of the reward system on employee performance is rejected or not accepted. In this study, it can be informed that giving rewards to employees that directly cannot affect employee work performance. This means that the high and low rewards given to employees do not necessarily provide better work performance effects.

Work precision cannot be done instantly by only giving as many rewards as possible, but it must be passed through a long process that can be done by strengthening education, competence, increasing capacity and accountability. To improve performance can not only be measured by giving high incentives, adequate salaries, decent remuneration or good promotion. Because giving directly has a tendency that is temporary.

When salaries have been paid, then it has become their rights and obligations. When incentives have been given it is a reward for employee employment. When remuneration has been given, then it has become an obligation of the government to be paid because it is part of its performance. Likewise when promotions are not provided give an impact on employee performance, because promotion is a level of position for every employee. Every employee has the same opportunity in getting everything. Achievements can be achieved with a long process and optimal performance.

The results of the study submitted by Armstrong and Taylor which states that the reward system is able to provide better changes to employee performance (Armstrong \& Taylor, 2014). What was conveyed by Armstrong and Taylor is more about the aspect of change in performance, not on the aspect of achievement which shows that the employee provides an increase in performance both in quantity and quality, in the aspect of effectiveness and efficiency. As a comparison is the speed of employees in completing their work, the quality of services provided to the community and the achievement of goals to be achieved.

Although the description of the reward system variables on 4 (four) indicators is fairly high which is seen in table 5 with an average of 3.95 and on the description of variable table 4 and the factor loading of each indicator is also high, but based on aspects of the reality of observation in The field shows that the reward system applied is considered as a reward for his work. Reward system is a total reward from work that has been completed. After completing work, the employee gets his rights such as salary, incentives, remuneration and promotion. The reward system also meant as compensation for workers, so the work presentation is not due 
to a reward. Work performance is more influenced by motivation and discipline achieved with a certain time and certain work as well.

\section{The Role of Religiosity as Moderation in the Effect of Motivation on Work Performance}

The results of data analysis show that the role of religiosity as moderation in the influence of motivation on work performance is not accepted or rejected and it is not significant. This can be seen in Table 6 of the path coefficients and P-Value obtained. There is a tendency of employees or state civil apparatus to separate between religious affairs and work affairs. Religious affairs are matters of worship addressed directly to their Lord, while matters of work are matters of their self with the organization where he works

The influence of motivation on work performance does not have a significant effect and even has a tendency to weaken. When seen from the aspect of measurement of religiosity variables have a high score, there are even some items that have a very high score, this can be seen in table 4. Meaning that the level of religiosity of employees in 3 (three) offices in the local government of Malang City has a good level of religiosity. Even believing in the existence of God and carrying out all commands and avoiding all his prohibitions is a necessity. Obedience to his Lord is also a measured part and gets a high enough score.

The religiosity values do not have a positive tendency when faced with aspects of their work. This means that the motivation of employees in their work has no connection with the values of religiosity. Believing that religion teaches goodness and truth in life is true, but makes religion appropriate things that strengthen the motivation of employees to be more accomplished in their work turned out to have no impact. In fact in the Qur'an Adz Dzariyat (56) asserted that God created the Jinn and humans are solely for worship. The simplest understanding is that what every human being does is actually part of worshiping Allah Almighty. The value of worship is not only related directly to God, but relations with humans also become worship when intended and carried out in accordance with the provisions and values of religiosity.

The results of this study are also not in line with what was stated by Setiawan (2005) which states that the role of religiosity has a positive and significant influence on motivation and work performance. The aspect of religiosity is categorized as a form of behavior of a person who is within himself and is practiced in daily life, including when working shows strong motivation to be able to provide the best for his organization. The motivation is getting higher and has an influence on his work performance.

Therefore, the results of this study provide information that, the high value of religiosity cannot be used as a sign that it can reinforce work motivation for achievement. The religious relationship possessed by a person does not necessarily affect the attitudes and behavior of his work. 


\section{The Role of Religiosity as Moderation in the Effect of Reward Systems on work Performance}

The results of this study showed no positive and significant influence on the role of religiosity as moderation in the effect of reward systems on employee work performance. Religious knowledge and the practice of religious values do not negate can affect the rewarding of work performance. This can be seen in table 6 with the coefficient and P-Value higher than 0.05 which shows that religiosity does not have a role in the effect of reward on work performance

Employees who have strong religious values when given a reward do not guarantee that they will achieve more. It is true that religious values cannot be linked to work values. This assumption can be justified from the results of this study. That employees work according to their needs and not serve as worship. Work attached to him is purely his work and cannot be linked to religious values.

From the results of this study, it can be seen the average age range of employees is less than 30 years to 40 years. Employees in the local government service in Malang City have an average productive age and only about 12 people have an age above 51 years. This means that the young age of employees has a tendency to put aside the values of religiosity in their work. In the productive age, the tendency to work hard and collect the coffers (worldly affairs) especially in the millennial era as it is today, where human beings are realized with the principle of instant, which is easy to obtain, it only focuses on how to work according to the targets needed and completed according in the hopes of his boss.

The religiosity value as part of the moderation of the effect of the reward system on work performance tends to weaken. This means that the existence of religious values has no role at all in aspects of employee work. Employees never involve aspects of religiosity in aspects of their work. In working, the fear is only with the rules and superiors. In improving achievement, they only want to be valued by their supervisors and only to be praised by their colleagues. This can be seen in table 6 with a loading factor of -0.018 and p-value of 0.420 .

The results of this study are also not in line with the results of the study are not in line with what has been said by Allah in the Koran. Though Allah has given a warning, which means: He is the one who made the earth easy for you, then, walk in all its corners and eat some of His sustenance, and only to Him (you) are raised (QS al-Mulk (67) : 15). Likewise, in Surat al-Jumuah verse 62, Allah SWT confirms that when the prayer has performed, then you will scatter on the face of the earth; and seek the gift of God and remember God a lot so that you are lucky.

Inthe two verses above the God expressly states that it works and always remembers Allah in order to be a lucky person. Principally, life cannot be separated from religiosity or always remember to his Lord so that we do not fall into things that are forbidden by The God. Therefore, it is really important that God's existence is always the key for us to remember. Remembering it in working, it can avoid corruption, collusion and nepotism. Encouraging work in accordance with religious values at work is part of worship.So it will undoubtedly focus on and comply with the rules and regulations set by the organization, because those provisions are also a 
good part of being better. Then it will focus on giving the best to the organization and working as well as possible for the benefit of the organization.

\section{CONCLUSION}

Based on the results of research and discussion above the effect of the reward system on motivation has a positive and significant effect. Reward System is characterized by indicators of incentives, salaries, remuneration and promotions have a high level of influence on the rewards given to employees. Of the four indicators, salary indicators that have the highest score of reward received. This shows that salaries received by employees are already quite high and are significant as a form of reward system. The greater the Reward System will result in greater motivation.

The effect of the reward system on work performance has no positive and significant effect. Interms of indicators, the reward system has high and medium indicators, but it does not have a significant influence on work performance. The existence of a reward system does not have positive and significant implications for work performance. This means that work performance is not directly affected by reward, but must go through motivation and engagement media so that reward can significantly influence work performance.

The role of religiosity as moderation does not have a positive and significant effect on the influence of motivation on work performance. This is supported by the influence of motivation on work performance which also has no positive and significant effect. This means that this aspect of religiosity has no role in influencing motivation on work performance.

The role of religiosity as moderation does not have a positive and significant effect; it even weakens or does not strengthen the influence of the reward system on work performance. In fact, if there is no moderation of religiosity, the reward system has a positive and significant effect on work preservation. This means that the existence of religiosity does not support the existence of reward system of work performance.

\section{ACKNOWLEDGEMENTS}

This paper has no conflict of interest

\section{REFERENCES}

Armstrong, M. (2010). Armstrong's handbook of reward management practice:

Improving performance through reward. Kogan Page Publishers.

Armstrong, M., \& Taylor, S. (2014). Armstrong's Handbook of Human Resource

Management Practice: Edition 13. Kogan page.

Azizy, A. Q. A. (2007). Change management dalam reformasi birokrasi. Gramedia

Pustaka Utama.

Fowler. (1995). Development of Trust. Yogyakarta: Kanisius.

Pratheepkanth, P. (2011). Capital structure and financial performance: evidence

Religiosity Moderation On The Effect Of Reward System And Motivation On Work Performance 
from selected business companies in Colombo stock exchange Sri Lanka. Researchers World, 2(2), 171.

Putriani, Y. H., \& Shofawati, A. (2015). Pola perilaku konsumsi Islami mahasiswa Muslim Fakultas Ekonomi dan Bisnis Universitas Airlangga ditinjau dari tingkat religiusitas. Jurnal Ekonomi Syariah Teori Dan Terapan, 2(7).

Schaufeli, W. (2004). Utrecht Work Engagement Scale. Preliminary Manual. Retrieved February 10, 2020, from http://www.beanmanaged.eu

Setiawan, I. (2018). Regional Government Handbook. Retrieved February 10, 2020, from https://www.researchgate.net/publication/326458914

Tohardi, A. (2002). Practical understanding of human resource management. Bandung: Tanjung Pura University, Mandar Maju. 